\title{
Cefacetrile and Rifaximin
}

association might improve first

service conception rate and

reduce the number of services

per conception in cows with

clinical endometritis

Saleh Boudelal*, Mounir Adnane and Abdelatif Niar

\begin{abstract}
Clinical endometritis (CE) is a serious disease leading to poor reproductive performances in lactating dairy cows, thus diminishing farm profitability. To preserve optimum reproductive efficiency, various strategies and therapeutic approaches have been proposed to manage cows with CE, often with contradictory results. Thus, investigating new paths to CE treatment is economically important. The aim of the present study was to test the efficacy of three therapeutic protocols on the clinical cure rate of CE, and improvement of reproductive performance. Cows with CE $(n=42), 21-38$ days in milk (DIM), were assigned to three treatment groups: PGF: cows $(n=19)$ were treated systemically with two doses of d-cloprostenol, a PGF $2 \alpha$ analogue, at 14-days intervals; CEFAX: cows $(n=10)$ received an intrauterine infusion of the combined antibiotics Cefacetrile and

Rifaximin; and NAX: cows $(n=13)$ received systemic treatment with Ceftiofur crystalline free acid (CCFA). A control group included cows $(n=36)$ free from CE (healthy group: HE). All cows were clinically re-examined after the end of the treatment protocol. The clinical cure rate was $73.7 \%, 80 \%$ and $69.2 \%$ in PGF, CEFAX, and NAX groups, respectively $(P>0.05)$. The HE group had a significantly shorter calving to first service interval compared to CEFAX and PGF groups $(P<0.05)$, however the difference was not significant with NAX group. The mean calving to fertilizing service interval (CFI) was slightly higher in all three treatment groups compared to the HE group, however the difference was not significant $(P>0.05)$. CEFAX protocol resulted in shorter but not statistically significant CFI, compared to the PGF and NAX protocols. Services per conception rate were slightly lower (1.7) in the
\end{abstract}

Saleh BOUDELAL*, (Corresponding author, e-mail: salah.boudelal@univ-tiaret.dz), Laboratory of Farm Animals Reproduction, Institute of Veterinary Science, University of Tiaret, Algeria; Mounir ADNANE, Institute of Veterinary Sciences, University of Tiaret, Algeria; Abdelatif NIAR, Laboratory of Farm Animals Reproduction, Institute of Veterinary Science, University of Tiaret, Algeria 
CEFAX group compared to HE (1.75), PGF (1.84) and NAX (2.23) groups, however these differences were not significant. First service conception rate and conception rate at 105 DIM did not differ statistically between the treatment groups. While the difference was not significant, CEFAX protocol had slightly better cure rate for $\mathrm{CE}$, reducing the number of services per conception and boosting the resumption of ovarian activity after calving. Validating these finding on a larger herd size will improve the accuracy of these findings.

Key words: clinical endometritis; treatment; cure rate; reproductive performance

\section{Introduction}

During parturition and soon after calving, in most cows, the uterus is invaded mainly by commensal and opportunistic bacteria (i.e. Escherichia coli, Trueperella pyogenes, and Fusobacterium necrophorum) (Williams et al., 2005; Malinowski et al., 2011; Brick et al., 2012; Szenci et al., 2018). Uterine involution is the physiological process leading to epithelium regeneration, endometrial repair, microbial clearance of the uterine lumen and resumption of ovarian activity (Sheldon, 2004; Kočila et al., 2013; Sheldon and Owens, 2017).

Several clinical trials have shown that clinical endometritis (CE) declines reproductive efficiency in dairy cows, indirectly lowering farm profitability (Kim and Kang, 2003; Brick et al., 2012; Giuliodori et al., 2013; Đuričić et al., 2014). CE is an afebrile inflammation of the endometrium, diagnosed by the detection of abnormal uterine discharges in the vagina beyond 21 days in milk (DIM) (Sheldon et al., 2006). The disease is highly prevalent, affecting about $40 \%$ of lactating dairy cows (Kaufmann et al., 2010; Ahmadi et al., 2019).

The diagnosis of CE can be conducted by rectal palpation searching for uterine fluctuation or by vaginal examination (e.g. vaginoscopy or Metricheck ${ }^{\circledR}$ ) based on clinical symptoms, mainly pus and a fetid odour of vaginal discharges (VDs) (Runciman et al., 2009). Furthermore, CE can be diagnosed subclinically by uterine biopsy or cytology to detect uterine inflammation (Földi et al., 2006). Once CE is diagnosed, a good treatment protocol should be applied. However, CE therapy is greatly debated in the context of its effect on reproductive performances of dairy cows (i.e., first service conception rate (FSCR), calving to first service interval (CFSI), calving to fertilizing service interval (CFI), and number of services per conception (NSPC)). Treatment effectiveness depends on the medicines administered, postpartum period of treatment, stage of uterine involution, and ovarian activity (Lefebvre and Stock, 2012). Various remedies have been proposed, including uterine antibiotics (Mari et al., 2012; Tison et al., 2017), systemic antibiotics (Kaufmann et al., 2010; Brick et al., 2012), antiseptics (Mido et al., 2016), enzymes (Drillich et al., 2005), dextrose (Brick et al., 2012; Ahmadi et al., 2019), liquid paraffin (Makki et al., 2017), nonsteroidal anti-inflammatory drugs (NSAIDs) (Königsson et al., 2001), hormones (e.g. PGF $_{2 \alpha}$ ) (Kasimanickam et al., 2005) and homeopathic remedies (Arlt et al., 2009), all of which have been widely tested.

The aim of the present study was to compare the clinical cure rate of three therapeutic protocols using systemic prostaglandin $\left(\mathrm{PGF}_{2 \alpha}\right)$ analogues (d-cloprostenol), intrauterine application of intramammary applicators composed of an antibiotic association (Cefacetrile+Rifaximin), and a systemic antibiotic (Ceftiofur crystalline free acid: 
CCFA) in cows suffering from CE, and to assess the effects of these protocols on reproductive performance in comparison with healthy cows.

\section{Materials and methods}

\section{Animals}

The study was conducted between April 2018 and December 2019 on six dairy farms in Sougueur, in centralwest Algeria. All farms had an annual breeding system, and no synchronization programmes for oestrus or ovulation were used. Cows were housed in loose housing system with a similar feeding system (the ration consisted of meadow fodder or corn silage with vetch oats hay, and commercial concentrates were added according to milk yield). Water was given ad libitum. Animals were milked twice a day and the average daily milk production was $13.7 \pm 0.6 \mathrm{~kg} / \mathrm{cow}$. The body condition score (BCS) of the selected animals ranged between 2.75 and 3.25 according to criteria proposed by Ferguson et al. (1994).

\section{Gynaecological examination and enrolment criteria}

Only cows between 21 and 38 DIM (Exam 1) were included in the study. The perineal region was clinically inspected to detect abnormal VDs, while rectal palpation and vaginoscopy were used to determine the origin of VDs (Plöntzke et al., 2011). Transrectal ultrasound examinations (Dramanski I-Scan, Dramanski ${ }^{\circledR}$ animal profi, Poland) were performed to monitor uterine liquid accumulation, wall thickness, uterine lumen diameter and ovarian structures. VDs were scored according to Williams et al. (2005). Cows with VDs $\geq 1$ were considered as having CE (Madoz et al., 2017; Tison et al., 2017). Cows having vaginal laceration at calving or were subject to caesarean section and/or received any intrauterine or systemic antibiotic or hormonal treatment during the last 15 days before the start of the study were excluded. After the onset of the experimental study, any cow receiving a treatment for other diseases than CE was excluded. Cows that were culled or sold before the pregnancy diagnosis were excluded from the analysis.

\section{Treatment protocols}

Cows were randomly allocated to four experimental groups, as follows. The PGF protocol included 19 cows that received two intramuscular injection of $150 \mu \mathrm{g}$ d-cloprostenol a PGF $_{2 \alpha}$ analogue $\left(\right.$ Dalmazin $^{\circledR}$, FATRO S.p.A. Veterinary Pharmaceutical Industry, Via Emilia, 285, 40064 Ozzanodell'Emilia (Bologna), Italy) at 14-day intervals. The CEFAX protocol included 10 cows that received simultaneous intrauterine infusion of two intramammary applicators (Cefaximin-L spray $^{\circledR}$, FATRO S.p.A., Italy). Each $15 \mathrm{~g}$ applicator contains the antibiotic association of Cefacetrile (200 mg) and Rifaximin (100 mg), the mixture was infused in the uterus using a solid stainless-steel rod of $50 \mathrm{~cm}$ in length. The NAX protocol included 13 cows that received a single dose of 6.6 $\mathrm{mg} / \mathrm{kg}$ of bodyweight (BW) of CCFA subcutaneously behind the ear $\left(\mathrm{Naxcel}^{\circledR}\right.$, Zoetis, USA). The HE group included 36 healthy cows without clinical symptoms of CE. To determine the cure rate of protocols, all treated cows were reexamined two weeks after the end of the treatment (Exam 2) (35-53 DIM). The clinical cure was defined as a cow with $\mathrm{CE}$ at Exam 1 that was subsequently described as clinically healthy (VDs=0) at Exam 2. Reproductive parameters were defined and are summarized in Table 1 . The voluntary waiting period was set at 50 days postpartum, and pregnancy controls were performed by transrectal ultrasonography at $35 \pm 4$ days post mating. The study was carried 
Table 1. Definitions of reproductive parameters for evaluating the effect of the treatment protocol in dairy cows

\begin{tabular}{l|l|}
\hline Parameters & Definition \\
\hline $\begin{array}{l}\text { Cure rate (\%) } \\
\begin{array}{l}\text { Calving to first service interval } \\
\text { (CFSI) (days) }\end{array}\end{array}$ & $\begin{array}{l}\text { The number of cured cows on day } 14 \text { divided by the } \\
\text { number of treated cows in each group*100 }\end{array}$ \\
\hline $\begin{array}{l}\text { Calving to fertilizing service } \\
\text { interval (CFI) (days) }\end{array}$ & The number of days from calving to successful service \\
\hline $\begin{array}{l}\text { Number of services per } \\
\text { conception (NSPC) }\end{array}$ & The number of services required to get a cow pregnant \\
\hline $\begin{array}{l}\text { First service conception rate } \\
\text { (FSCR) (\%) }\end{array}$ & $\begin{array}{l}\text { The number of cows get pregnant at first service divided } \\
\text { by the total number of serviced cows*100 }\end{array}$ \\
\hline $\begin{array}{l}\text { Conception rate at } 105 \text { DIM } \\
\text { (CR105) (\%) }\end{array}$ & $\begin{array}{l}\text { The number of pregnant cows until } 105 \text { days divided by } \\
\text { the total number of mated cows *100 }\end{array}$ \\
\hline
\end{tabular}

out according to the guidelines of the Institutional Animal Care Committee of the Algerian Higher Education and Scientific Research.

\section{Statistical analysis}

Data were analysed using IBM SPSS version 24.0. (IBM SPSS Statistics for Windows, Version 24, USA). Cure rate, first service conception rate (FSCR), and conception rate until 105 DIM (CR105) were compared among the experimental groups using the Chi-square test or Fisher's exact test. Reproductive parameter data (calving to first service interval (CFSI), calving to fertilizing service interval (CFI), and number of services per conception (NSPC)) were presented as means \pm standard deviation (SD), and the Mann-Whitney nonparametric U-test was used for statistical comparison between groups. Statistical significance was set at $P<0.05$.

\section{Results}

The clinical cure rate of CE cows was $73.7 \%, 80 \%$ and $69.2 \%$ for PGF, CEFAX, and NAX protocols, respectively $(P>0.05)$. FSCR did not differ significant between

Table 2. Cure rate and reproductive performances indices in the control and treatment protocols.

\begin{tabular}{|l|c|c|c|c|}
\hline Parameters & Healthy & PGF & CEFAX & NAX \\
\hline Cure rate $\%(n)$ & - & $73.7(14 / 19)$ & $80(8 / 10)$ & $69.2(9 / 13)$ \\
\hline FSCR $\%(n)$ & $36.1(13 / 36)$ & $36.8(7 / 19)$ & $40(4 / 10)$ & $23.1(3 / 13)$ \\
\hline CR105 $(n)$ & $86.1(31 / 36)$ & $73.7(14 / 19)$ & $70(7 / 10)$ & $69.2(9 / 13)$ \\
\hline CFSI $($ mean \pm SD) days & $59.94 \pm 11.64^{\mathrm{a}}$ & $75.21 \pm 27.08^{\mathrm{b}}$ & $69.90 \pm 8.42^{\mathrm{b}}$ & $67.69 \pm 13.2$ \\
\hline CFI (mean \pm SD) days & $76.50 \pm 17.74$ & $93.32 \pm 35.43$ & $85.70 \pm 21.25$ & $94.0 \pm 30.92$ \\
\hline NSP (mean \pm SD) days & $1.75 \pm 0.69$ & $1.84 \pm 0.83$ & $1.70 \pm 0.67$ & $2.23 \pm 1.01$ \\
\hline
\end{tabular}

Values in lines with different letters $\left(\stackrel{a}{a},{ }^{b}\right)$ are significantly different $(P<0.05)$. FSCR $=$ First service conception rate; CR105= Conception rate at 105 DIM; CFSI = calving to first service interval; CFI= calving to fertilizing service interval; $\mathrm{NSPC}=$ number of services per conception 
any treatment protocol and the control group $(P>0.05)$. The lowest FSCR was found in the NAX group (23.1\%). The highest CR105 was found in the HE group $(86.1 \%)$, however the difference was not significant between any treatment protocols and the control group $(P>0.05)$. CFSI was significantly higher in both the PGF (75.21 \pm 27.08$)$ and CEFAX groups (69.90 \pm 8.42$)$ compared to HE group (59.94 $\pm 11.64) \quad(P<0.05)$. Compared to the HE group, CFI was about 17 days (d), $9 \mathrm{~d}$, and 18d longer in the PGF, CEFAX and NAX groups, respectively, though differences were not significant $(P>0.05)$. NSPC was slightly lower (1.7) in the CEFAX group compared to the HE (1.75), PGF (1.84) and NAX (2.23) groups, though differences were not significant $(P>0.05)$ (Table 2$)$.

\section{Discussion}

Clinical endometritis is an important postpartum uterine disease that alters normal reproductive performance, reducing subsequent fertility and thus has a negative impact on the farm profitability. The aim of this study was to evaluate the effect of different treatment protocols in cows with CE on the clinical cure rate and reproductive performance.

The selected protocols were based on in vitro findings where Ceftiofur, a third generation cephalosporin, Cephapirin, a first generation cephalosporin, and Rifaximin, a semi- synthetic antibiotic, were concluded to be effective in the treatment of uterine infection (Malinowski et al., 2011). The three molecules are broad spectrum antibiotics and active against gram-positive and gram-negative bacteria, even in an anaerobic environment. Furthermore, Galvão et al. (2009), reported that using intramammary applicators of Ceftiofur $(125 \mathrm{mg})$ by intrauterine route resulted in concentrations of Ceftiofur in uterine fluids $(>0.50 \mu \mathrm{g} / \mathrm{mL})$ sufficient to inhibit growth of relevant pathogens involved in uterine infections during the first two months of calving (Witte et al., 2011). Since CE is a pathological inflammation of the endometrium, Flammini et al. (2018) revealed surprising anti-inflammatory properties of Rifaximin on the bovine endometrial cell challenged with Lipopolysaccharide (LPS) of Escherichia coli.

The prostaglandin $\mathrm{F}_{2 \alpha}$ has been commonly used as remedy for postpartum diseases. Several studies have revealed that $\mathrm{PGF}_{2 \alpha}$ and its analogues effectively improve reproductive performance and increase the cure rate of uterine diseases (Ahmadi et al., 2018), especially those associated with the presence of corpus luteum (CL). In the literature, it seems that using two injections of $\mathrm{PGF}_{2 \alpha}$ at a 14-day interval is the most common and effective therapeutic protocol for CE (Lefebre and Stock, 2012). The use of $\mathrm{PGF}_{2 \alpha}$ in CE therapy is intended to induce luteolysis of CL, boost uterine contraction and thus accelerate the uterine involution and the resumption of ovarian activity, which will reduce the occurrence of CE (Hoedemaker, 1998; Kasimanickam et al., 2005). Furthermore, $\mathrm{PGF}_{2 \alpha}$ has immunological properties, as it increases uterine leukotriene B4 secretions that supports chemotaxis, cell-mediated cytotoxicity, phagocytosis, and lymphocyte function, all of which will control and modulate uterine inflammation (Slama et al., 1993; Lefebvre and Stock, 2012). Although, it has been demonstrated that a systemic antimicrobial treatment of CE is not justified since the possible infection in the case of CE is limited to the superficial layer of the endometrium (Földi et al., 2006), Kaufmann et al. (2010) reported that systemic treatment with $1.0 \mathrm{mg} / \mathrm{kg}$ BW of Ceftiofur over three consecutive days in cows with signs of clinical endometritis 21-27 DIM had the same effect as treatment with two doses of $\mathrm{PGF}_{2 \alpha}$ at a 14-day interval. Also, systemic antibiotic administration may provide equal distribution of a therapeutic concentration to different 
organs, preventing possible passage of bacteria to the uterus. Witte et al. (2011) reported that subcutaneous administration of CCFA $(6.6 \mathrm{mg} / \mathrm{kg} \mathrm{BW})$ after parturition for healthy puerperal dairy cows with normal parturition resulted in effective and durable concentrations of Ceftiofur derivatives in endometrial tissues and lochia that exceed the recommended minimal inhibitory concentrations for many pathogens detected in genital tract pathologies, mainly Escherichia coli, Trueperella pyogenes, Fusobacterium necrophorum and Prevotella melaninogenica. In their study, the mean concentration of desfuroylceftiofur acetamide, the active metabolite of Ceftiofur reached its highest level in the endometrial tissue $24 \mathrm{~h}$ after systemic administration of CCFA, and remained high until day 7 , after which it started to decline.

In the current study, the clinical cure rate in the three treatment groups was around $70 \%$. These results indicated that the three treatments helped to clinically resolve CE. In a previous study, the clinical cure rate of systemic Ceftiofur or two doses of $\mathrm{PGF}_{2 \alpha}$ was $74.2 \%$ and $80.2 \%$, respectively (Kaufmann et al., 2010), which is similar to our findings. Also, Mari et al. (2012) established a scoring system for evaluating CE severity where a higher score indicates a more severe case of CE. The authors found that intrauterine infusion of $500 \mathrm{mg}$ Cephapirin, a first generation cephalosporin having similar activity to Cefacetrile, decreased the score value from 5.91 to 1.0 three weeks after treatment. The likelihood for clinical cure decreased with VD score (Eslami et al., 2015) and the severity of endometrial lesions and the detection of Trueperella pyogenes (Madoz et al., 2017).

The conception rate of the HE group and treated cows did not differ significantly among groups at 105 DIM $(71.4 \%$ in average for treated groups vs $86.1 \%$ in HE group) $(P>0.05)$. This result is consistent with Ahmadi et al.
(2018), who found that the percentage of pregnant cows at 100 and 200 DIM was similar among groups ( $46 \%$ in average at 100 DIM and $82 \%$ at 200 DIM). Soon after calving, cows are inevitably exposed to a negative energy balance that affects the effectiveness of immune function and metabolism, resulting in several diseases (Giuliodori et al., 2013). However, adjusting animal feeding is effective in reducing the effects of negative energy balance and preventing BCS loss (Galvão, 2013).

To be highly effective, CE treatment should not only increase the cure rate but also improve the reproductive performance of the female. Cows in the HE group had a significantly shorter CFSI compared to the three treatment groups. The median time to first service was about $15 \mathrm{~d}, 10 \mathrm{~d}$, and $8 \mathrm{~d}$ higher in the PGF, CEFAX and NAX groups, respectively. $\mathrm{CE}$ is an inflammation of the endometrium and often associated with disruption of the endometrial epithelium and reduction and dysfunction of endometrial glands (Sheldon et al., 2009b; Adnane et al., 2018), extending uterine involution and delays the resumption of normal ovarian activity and pregnancy (Tison et al., 2017).

While the difference was not significant, the highest number of services per conception was shown in NAX groups compared to the other groups. This could be explained by the fact that the effective concentration of the antibiotic did not reach the endometrium in the appropriate time and for the required duration, or the endometrium was affected by pathogens resistant to Ceftiofur (Malinowski et al., 2011). Santos et al. (2010) reported that $38.9 \%$ of Trueperella pyogenes isolates were resistant to Ceftiofur. Likewise, intrauterine infusion of Ceftiofur reduced bacterial contamination of the uterus, decreased the prevalence of CE but failed to reduce the prevalence of subclinical endometritis 
(Galvão et al., 2009). Since endometritis is a pathological inflammation and the causative relation with bacteria is highly debated, many researchers assumed that even after the resolution of clinical symptoms of the disease, subfertility associated with endometritis persists (Eslami et al., 2015), and subclinical endometritis may develop (Sheldon et al., 2009a). Unfortunately, we did not diagnose subclinical endometritis as it was beyond the scope of this study. The cytological cure rate based on the neutrophil level in the endometrium was higher in cows with $\mathrm{CE}$ that received intrauterine Cephapirin or systemic PGF $_{2 \alpha}$ at 28-35 DIM compared to untreated cows (Makki et al., 2017). Therefore, associating the cytological cure rate with the clinical diagnosis would assist in determining which treatment protocol is more effective for $\mathrm{CE}$ treatment.

\section{Conclusion}

According to its effect on cure rate and reproductive performances, treatment with Cefaximin-L spray ${ }^{\circledR}$ intramammary applicators helped to resolve $\mathrm{CE}$ in dairy cows and to slightly improve the reproductive performances. We could not investigate the cytological cure rate as subclinical endometritis was not diagnosed. Further research on a larger sample size is planned to overcome this limit, as we believe that the reproductive parameters remained lower than normal due to the presence of subclinical inflammation in those animals, which required treatment other than antibiotics. Modulating uterine inflammation would be the next step toward endometritis management.

\section{Acknowledgements}

The authors thank participating farms and their staff for their cooperation and amiable hospitality.

\section{References}

1. ADNANE, M., K. G. MEADE and C. O'FARRELLY (2018): Cervico-vaginal mucus (CVM) - an accessible source of immunologically informative biomolecules. Vet. Res. Commun. 42, 255-263.

2. AHMADI, M. R., M. MAKKI, A. MIRZAEI and H. R. GHEISARI (2019): Effects of hypertonic dextrose and paraffin solution as non-antibiotic treatments of clinical endometritis on reproductive performance of high producing dairy cows. Reprod. Domest. Anim. 54, 762-771.

3. AHMADI, M. A., S. MOGHEISEH, A. MIRZAEI, S. NAZIFI and E. EISAFALLAH (2018): Treatment of cows with clinical endometritis III as cows affected by pyomètre-Non antibiotic treatment of severe clinical endometritis. Asian. Pac. J. Reprod. 7, 185-190.

4. ARLT, S., W. PADBERG, M. DRILLICH and W. HEUWIESER (2009): Efficacy of homeopathic remedies as prophylaxis of bovine endometritis. J. Dairy Sci. 92, 4945- 4953.

5. BRICK, T. A., G. M. SCHUENEMANN, S. BAS, J. B. DANIELS, C. R. PINTO, D. M. RINGS and P. J. RAJALA-SCHULTZ (2012): Effect of intrauterine dextrose or antibiotic therapy on reproductive performance of lactating dairy cows diagnosed with clinical endometritis. J. Dairy Sci. 95, 18941905.

6. DRILLICH, M., D. RAAB, M. WITTKE and W. HEUWIESER (2005): Treatment of chronic endometritis in dairy cows with an intrauterine application of enzymes. Theriogenology 6, 1811-1823.

7. ĐURIČIĆ, D., M. LIPAR and M. SAMARDŽIJA (2014): Ozone treatment of metritis and endometritis in Holstein cows. Vet. arhiv 84 103-110.

8. ESLAMI, M., M. BOLOURCHI, H. A. SEIFI, F. ASADI and R. AKBARI (2015): Treatment of clinical endometritis in dairy cows by previously used controlled internal drug release devices. Theriogenology 84, 437-445.

9. FERGUSON, J. D., D. T. GALLIGAN and N. THOMSEN (1994): Principal Descriptors of Body Condition Score in Holstein Cows. J. Dairy Sci. 77, 2695-2703.

10. FLAMMINI, L., L. MANTELLI, A. VOLPE, G. DOMENICHINI, R. DI LECCE, M. DONDI, A. M. CANTONI, E. BAROCELLI and F. QUINTAVALLA (2018): Rifaximin anti-inflammatory activity on bovine endometrium primary cell cultures: a preliminary study. Vet. Med. Sci. 4, 326-332.

11. FÖLDI, J., M. KULCSÁR, A. PÉCSI, B. HUYGHE, C. DE SA, J. A. C. M. LOHUIS and G. HUSZENICZA (2006): Bacterial complications of postpartum uterine involution in cattle. Anim. Reprod. Sci. 96, 265-281.

12. GALVÃO, K. N., L. F. GRECO, J. M. VILELA, M. F. SÁ FILHO and J. E. P. SANTOS (2009): Effect of intrauterine infusion of ceftiofur on uterine health and fertility in dairy cows. J. Dairy Sci. 92, 1532-1542. 
13. GALVÃO, K. N. (2013): Uterine diseases in dairy cows: understanding the causes and seeking solutions. Anim. Reprod. 10, 228-238

14. GIULIODORI, M. J., R. P. MAGNASCO, D. BECUVILLALOBOS, I. M. LACAU-MENGIDO, C. A. RISCO and R. L. DE LA SOTA (2013): Clinical endometritis in an Argentinean herd of dairy cows: Risk factos and reproductive efficiency. J. Dairy Sci. 96, 210-218.

15. HOEDEMAKER, M. (1998): Postpartum pathological vaginal discharge: to treat or not to treat. Reprod. Domest. Anim. 33, 141-146.

16. KASIMANICKAM, R., T. F. DUFFIELD, R. A. FOSTER, C. J. GARTLEY, K. E. LESLIE, J. S. WALTSON and W. H. JOHNSON (2005): The effect of a single administration of cephapirin or cloprostenol on the reproductive performance of dairy cows with subclinical endometritis. Theriogenology 63, 818-830.

17. KAUFMANN, T. B., S. WESTERMANN, M. DRILLICH, J. PLÖNTZKE and W. HEUWIESER (2010): Systemic antibiotic treatment of clinical endometritis in dairy cows with ceftiofur or two doses of cloprostenol in a 14-d interval. Anim. Reprod. Sci. 121, 55-62.

18. KIM, I. H and H. G. KANG (2003): Risk Factors for Postpartum Endometritis and the Effect of Endometritis on Reproductive Performance in Dairy Cows in Korea. J. Reprod. Develop. 49, 485-491.

19. KOČILA, A. JANŽEK, D. GRAČNER, T. DOBRANIĆ, D. ĐURIČIĆ, N. PRVANOVIĆ, N. FILIPOVIĆ, G. GREGURIĆ GRAČNER, LJ. BEDRICA, F. MARKOVIĆ and M. SAMARDŽIJA (2013): Vergleich von Progesteronkonzentrationen, Energiebilanzkennwerten und körperlicher Verfassung bei Milchkühen mit verschiedener Milchleistung im Puerperium. Tierärztl. Umsch. 68, 266-274.

20. LEFEBVRE, R. C and A. E. STOCK (2012): Therapeutic efficiency of antibiotics and prostaglandin F2 $\alpha$ in postpartum dairy cows with clinical endometritis: an evidence-based evaluation. Vet. Clin. Food. Anim. 28, 79-96.

21. MADOZ, L. V., I. PRUNNER, M. JAUREGUIBERRY, C. C. GELFERT, R. L. DE LA SOTA, M. J. GIULIODORI and M. DRILLICH (2017): Application of a bacteriological on-farm test to reduce antimicrobial usage in dairy cows with purulent vaginal discharge. J. Dairy Sci. 100, 3875-3882.

22. MAKKI, M., M. R. AHMADI, H. R. GHEISARI and S. NAZIFI (2017): Cure rate of postpartum endometritis after different treatments in high produce dairy cows. Comp. Clin. Pathol. 26, 921-928.

23. MALINOWSKI, E., H. LASSA, H. MARKIEWICZ, M. KAPTUR, M. NADOLNY, W. NIEWITECKI and J. ZIĘTARA (2011): Sensitivity to antibiotics of Arcanobacterium pyogenes and Escherichia coli from the uteri of cows with metritis/endometritis. Vet. J. 187, 234-238.

24. MARI, G., E. IACONO, F. TONI, P. G. PREDIERI and B. MERLO (2012): Evaluation of the effectiveness of intrauterine treatment with formosulphathiazole of clinical endometritis in postpartum dairy cows. Theriogenology 78, 189-200.

25. MIDO, S., N. MURATA, M. S. RAWY, G. KITAHARA and T. OSAWA (2016): Effects of intrauterine infusion of povidone-iodine on endometrial cytology and bacteriology in dairy cows with clinical endometritis. J. Vet. Med. Sci. 78, 551-556.

26. PLÖNTZKE, J., L.V. MADOZ, R. L. DE LA SOTA, W. HEUWIESER and M. DRILLICH (2011): Prevalence of clinical endometritis and its impact on reproductive performance in grazing dairy cattle in Argentina. Reprod. Domest. Anim. 46, 520-526.

27. RUNCIMAN, D., G. ANDERSON and J. MALMO (2009): Comparison of two methods of detecting purulent vaginal discharge in postpartum dairy cows and effect of intrauterine cephapirin on reproductive performance. Aust. Vet. J. 87, 369-378.

28. SANTOS, T. M.A., L. S. CAIXETA, V.S. MACHADO, A. K. RAUF, R. O. GILBERT and R. C. BICALHO (2010): Antimicrobial resistance and presence of virulence factor genes in Arcanobacterium pyogenes isolated from the uterus of postpartum dairy cows. Vet. Microbiol. 145, 84-89.

29. SHELDON, I. M. (2004): The postpartum uterus. Vet. Clin. North. Am. Food. Anim. Pract. 20, 569-591.

30. SHELDON, I. M., G. S. LEWIS, S. J. LEBLANC and R. O. GILBERT (2006): Defining postpartum uterine disease in cattle. Theriogenology 65, 1516-1530.

31. SHELDON, I. M., J. CRONIN, L. GOETZE, G. DONOFRIO and H. J. SCHUBERTH (2009a): Defining postpartum uterine disease and the mechanisms of infection and immunity in the female reproductive tract in cattle. Biol. Reprod. 8, 1025-1032.

32. SHELDON, I. M., S. PRICE, J. CRONIN, R. O. GILBERT and J. GADSBY (2009b): Mechanisms of infertility associated with clinical and subclinical endometritis in high producing dairy cattle. Reprod. Domest. Anim. 44, 1-9.

33. SHELDON, I. M. and S. E. OWENS (2017): Postpartum uterine infection and endometritis in dairy cattle. Proceedings of the $33^{\text {rd }}$ Annual Scientific Meeting of the European Embryo Transfer Association (AETE); Bath, United Kingdom, September $8^{\text {th }}$ and $9^{\text {th }}$.

34. SLAMA, H., D. VAILLANCOURT, and A. K. GOFF (1993): Leukotriene B4 in cows with normal calving and in cows with retained fetal membranes and/or uterine subinvolution. Can. J. Vet. Res. 57, 293-299.

35. SZENCI, O., Z. SZELÉNYI, L. LÉNÁRT, D. BUJÁK, L. KOVÁCS, L. F. KÉZÉR, B. HAN and A. HORVÁTH (2018): Importance of monitoring the peripartal period to increase reproductive performance in dairy cattle. Vet. stn. 49, 297-307. 
36. TISON, N., E. BOUCHARD, L. DESCÔTEAUX and R. C. LEFEBVRE (2017): Effectiveness of intrauterine treatment with cephapirin in dairy cows with purulent vaginal discharge. Theriogenology 89, 305-317.

37. WILLIAMS, E. J., D. P. FISCHER, D. U. PFEIFFER, G. C. W. ENGLAND, D. E. NOAKES, H. DOBSON and I. M. SHELDON (2005): Clinical evaluation of postpartum vaginal mucus reflects uterine bacterial infection and the immune response in cattle. Theriogenology 63, 102-117.

38. WITTE, T. S., M. IWERSEN, T. KAUFMANN, P. SCHERPENISSE, A. A. BERGWERFF and W. HEUWIESER (2011): Determination of ceftiofur derivatives in serum, endometrial tissue, and lochia in puerperal dairy cows after subcutaneous administration of ceftiofur crystalline free acid. J. Dairy Sci. 94, 284-290.

\section{Kombinacija cefacetrila i rifaksimina može poboljšati postotak prvog uspješnog osjemenjivanja i smanjiti broj osjemenjivanja po koncepciji u krava s kliničkim endometritisom}

Saleh BOUDELAL, Laboratory of Farm Animals Reproduction, Institute of Veterinary Science, Ibn Khaldoun University, Tiaret, Algeria; Mounir ADNANE, Institute of Veterinary Sciences, University of Tiaret, Algeria; Abdelatif NIAR, Laboratory of Farm Animals Reproduction, Institute of Veterinary Science, Ibn Khaldoun University, Tiaret, Algeria

Klinički endometritis (CE) jedna je od glavnih značajnih bolesti koja dovodi do lošeg reproduktivnog učinka mliječnih krava u laktaciji, a time smanjujući profitabilnost farme. $\mathrm{Da}$ bi se sačuvala optimalna reproduktivna učinkovitost, predložene su različite moguće strategije i terapijski pristupi za krave s CE-om, često s kontradiktornim rezultatima. Iz tog je razloga istraživanje novih načina liječenja CE-a ekonomski bitno. Cilj ove studije bio je ispitati učinkovitost tri različita terapijska protokola na postotak kliničkog izlječenja CE-a te poboljšanje reproduktivne učinkovitosti. Krave $(n=42)$, na 21.-38. dan laktacije (DIM), s CE-om raspoređene su $\mathrm{u}$ tri terapijske skupine; PGF: krave $(n=19)$ su sistematski liječene s dvije doze d-kloprostenola, sintetičkog analoga PGF $_{2 \alpha^{\prime}}$ 14-dnevni interval; CEFAX: krave $(n=10)$ su primale intrauterinu infuziju kombinacije antibiotika cefacetrila i rifaksimina; NAX: krave $(n=13)$ su primale sistemsku terapiju s ceftiofur kristaliničnom slobodnom kiselinom (CCFA). Trideset i šest $(n=36)$ krava bez CE-a (zdrava skupina: HE) uključeno je kao kontrolna skupina. Sve krave su ponovno klinički pregledane nakon kraja protokola liječenja. Postotak kliničkog izlječenja iznosio je $73,7 \%, 80 \%$ i $69,2 \%$ u PGF, CEFAX, odnosno NAX skupini $(P>0,05)$. HE skupina imala je značajno kraći interval između teljenja do prvog osjemenjivanja u usporedbi s CEFAX i PGF skupinama $(P<0,05)$, no razlika nije bila značajna s NAX skupinom. Srednji interval od teljenja do osjemenjivanja za oplodnju (CFI) bio je nešto veći $u$ tri terapijske skupine $u$ usporedbi s HE skupinom, ali razlika nije bila značajna $(P>0,05)$. CEFAX protokol rezultirao je kraćim, ali ne statistički značajnim CFI u usporedbi s PGF i NAX protokolima. Indeks osjemenjivanja po koncepciji bio je nešto niži $(1,7)$ u CEFAX skupini u usporedbi s HE $(1,75)$, PGF $(1,84)$ i NAX $(2,23)$ skupinama, međutim razlika nije bila značajna između sve četiri skupine. Postotak prvog uspješnog osjemenjivanja i postotak koncepcije na 105. DIM nisu se statistički razlikovale među terapijskim skupinama. Premda razlika nije bila značajna, CEFAX protokol imao je nešto bolji postotak izlječenja za CE, smanjujući broj osjemenjivanja po koncepciji i potičući ponovnu aktivnost jajnika nakon teljenja. Validacija ovog otkrića na većem krdu poboljšat će točnost ovih rezultata.

Ključne riječi: klinički endometritis, liječenje, postotak izlječenja, reproduktivna učinkovitost 